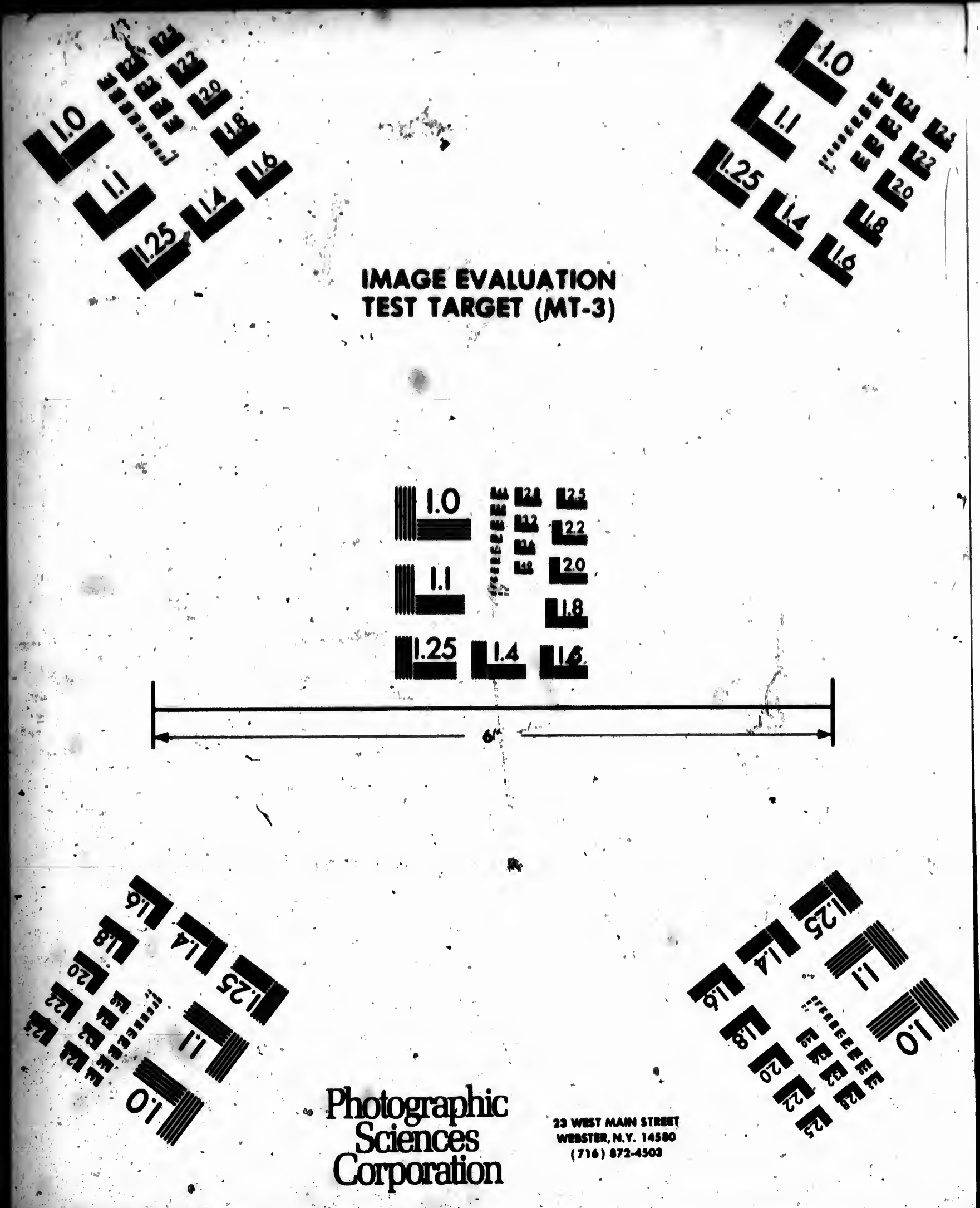




\section{CIHM Microfiche Series (Monographs)}

\section{ICMH \\ Collection de microfiches (monographies)}

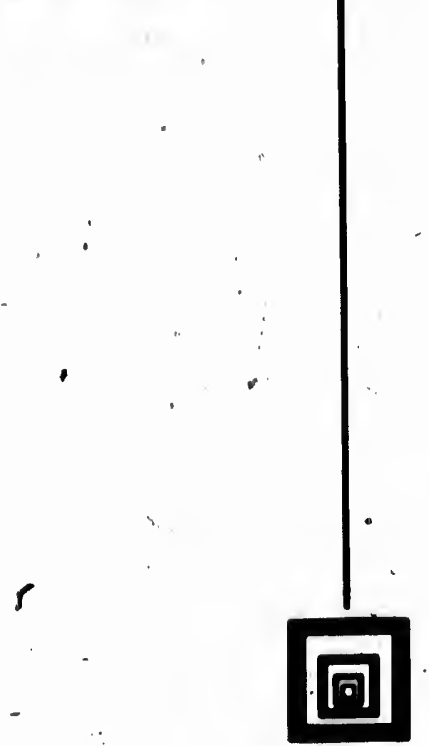

sot
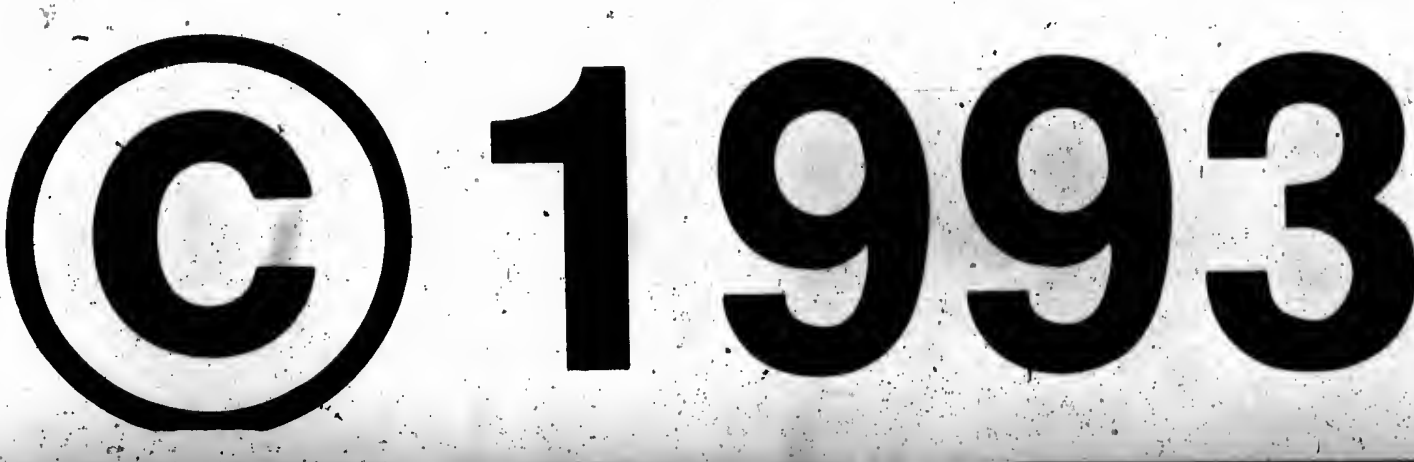


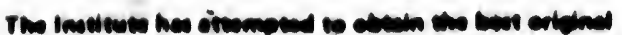

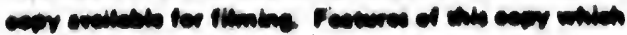

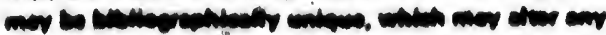

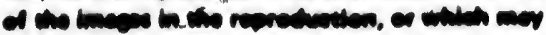

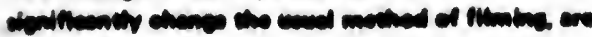

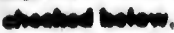

$\square$

Chomond cemond

Convenure to conimese

Comere trimenty

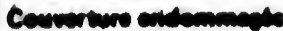

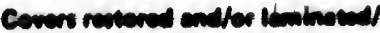

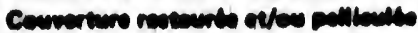

Cover uth mbeing

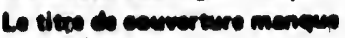

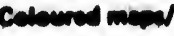

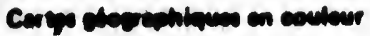

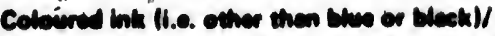

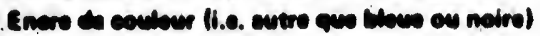

Colowned dowes end/or illuptrational

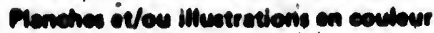

t)

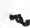

Coundwith othis menriel/,

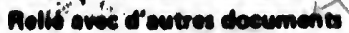

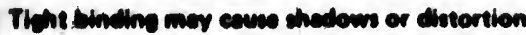
cleasy intries meriml

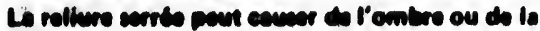

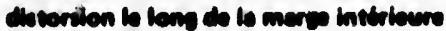

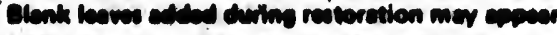

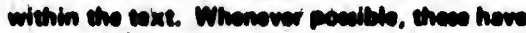
men endrind frem filoniny

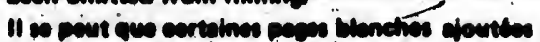

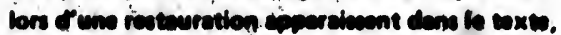

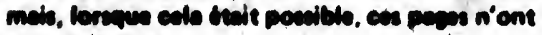
ien hes tininise.

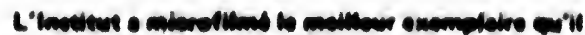

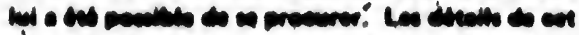

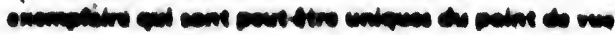
"

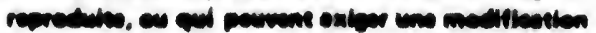

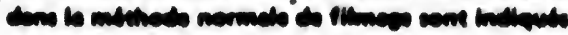

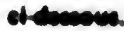

$$
\text { \% }
$$

Conimed ened

rem to ceculan

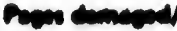

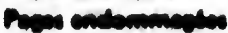

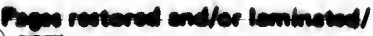

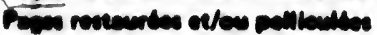

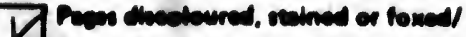

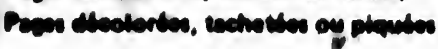

Prews dotacinal.

Peres cheretries

Showthroun/

Treminerence

Ouellity of point veripal

Oualins incedes is limpression

Continuous pedmation/

Pesinution continus

includes indox(ea)/

Comprend un (ceal indox

Tith on minent icken trom:/

Le titus es lien-tite proviont:

Titio peep of 'bacel

Pees es titre do fo liwration

Caption of iseul

Titre do dipert de la livereison

Mosthead

Cindriaus (phriodiawes) do la tivraison

$\nabla$

Aditiond eomments:/

Commenntaires expollementuires:

Th1s copy 1s a photoreproduction.

\section{4,}

This basi is fllmed ot the reduction rotio eheeted bolow/

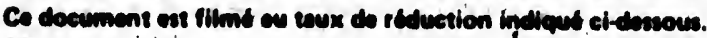

$10 x$

$14 x$

$10 x$

$22 x$

$26 x$

$30 x$

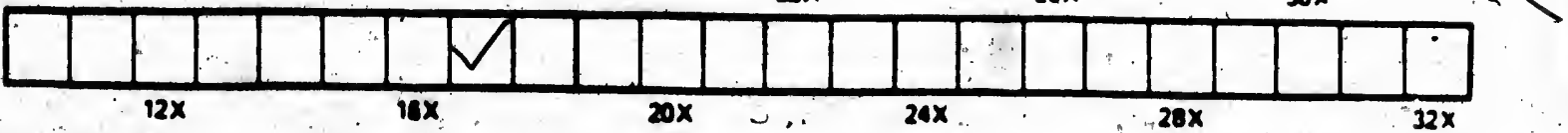




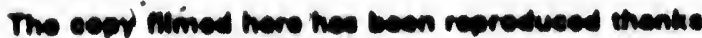
to the cencrealty of:

$$
\begin{aligned}
& \text { Universicy of Toronto, } \\
& \text { Sclence S Medicineat Ibrery }
\end{aligned}
$$

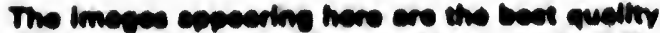

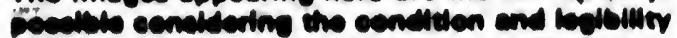

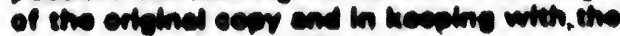

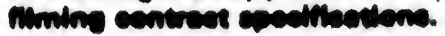

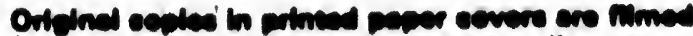

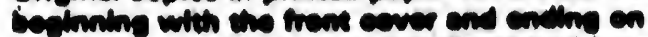

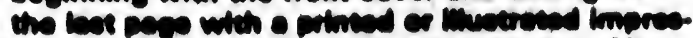

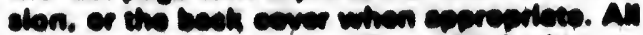

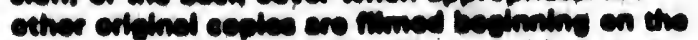

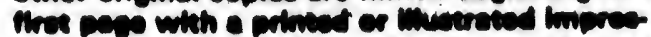

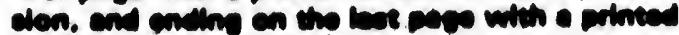

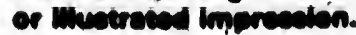

The lant resended treme en cech miereflethe chell semeln the eymbel $\rightarrow$ Imeaning "CON. THNULO"). of the ormbel 7 (meaning "END"). monetrower enalles.

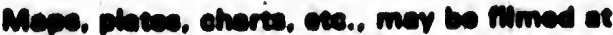

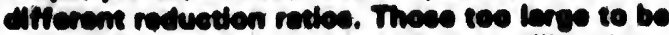

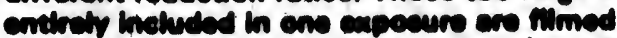

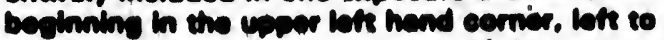
Hoht end top to bettom. co many fremes es requiled. The following desereme theserese the mothod:

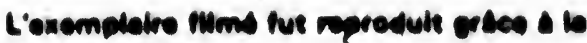
compresies de:

University of Toronto, Sclance Hedicine LIbrary

Les Imeces eurvemes ont we repredultes owe b

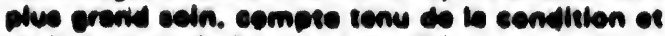

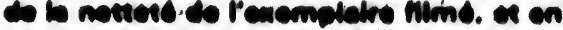

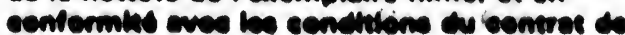
Hinees.

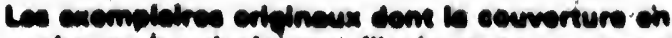

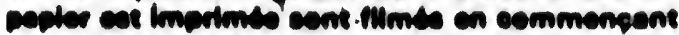

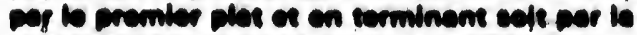

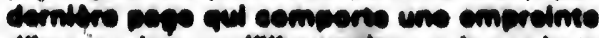

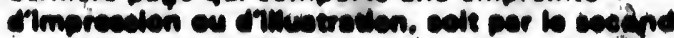

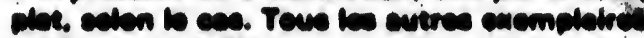

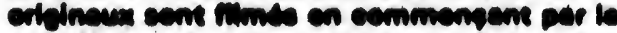

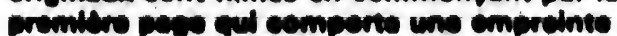

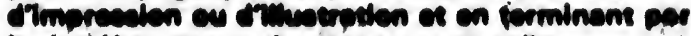

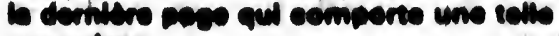
emprime.

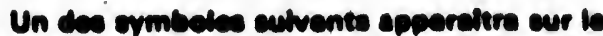

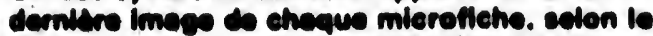
cas: to crmbels clowite "A suivine". b. ermbele $\nabla$ cienifie "Fin".

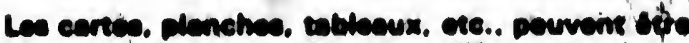
nimbe des taur do riduction diticrents.

Lorsace b desumem cot tres grend pous ctre

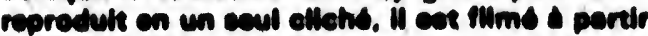

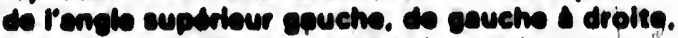
et depheut en bes; en preneme lo nombre

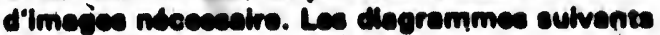
Mustreme lo methode.
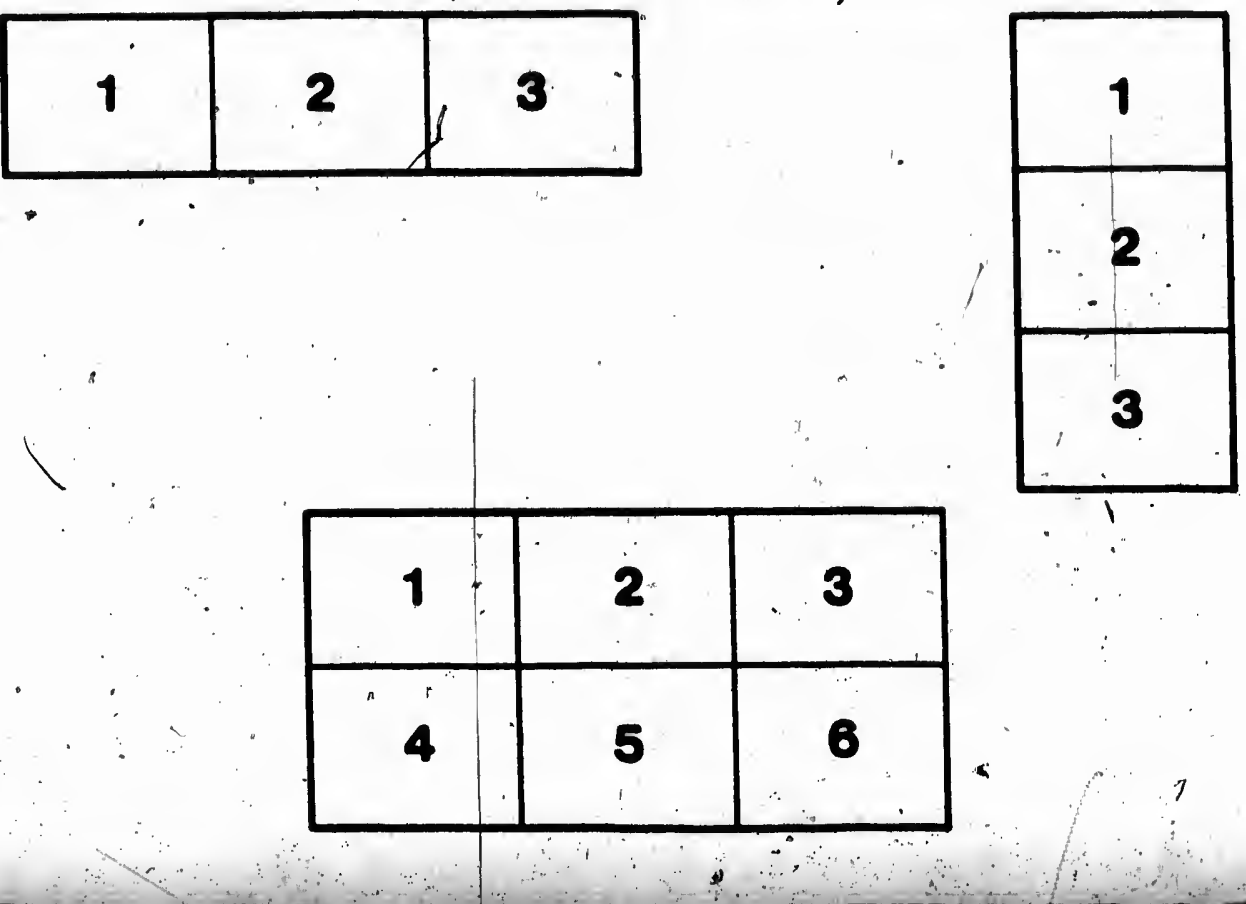


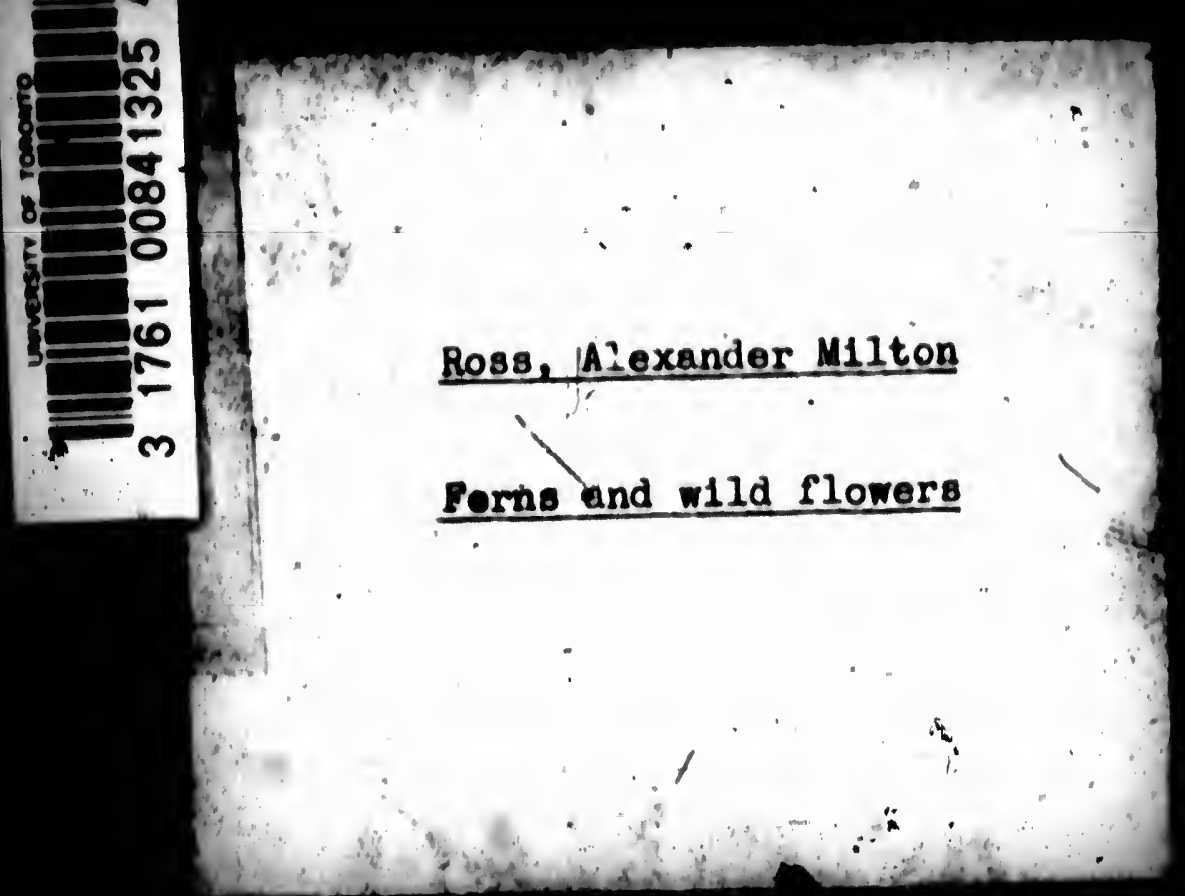




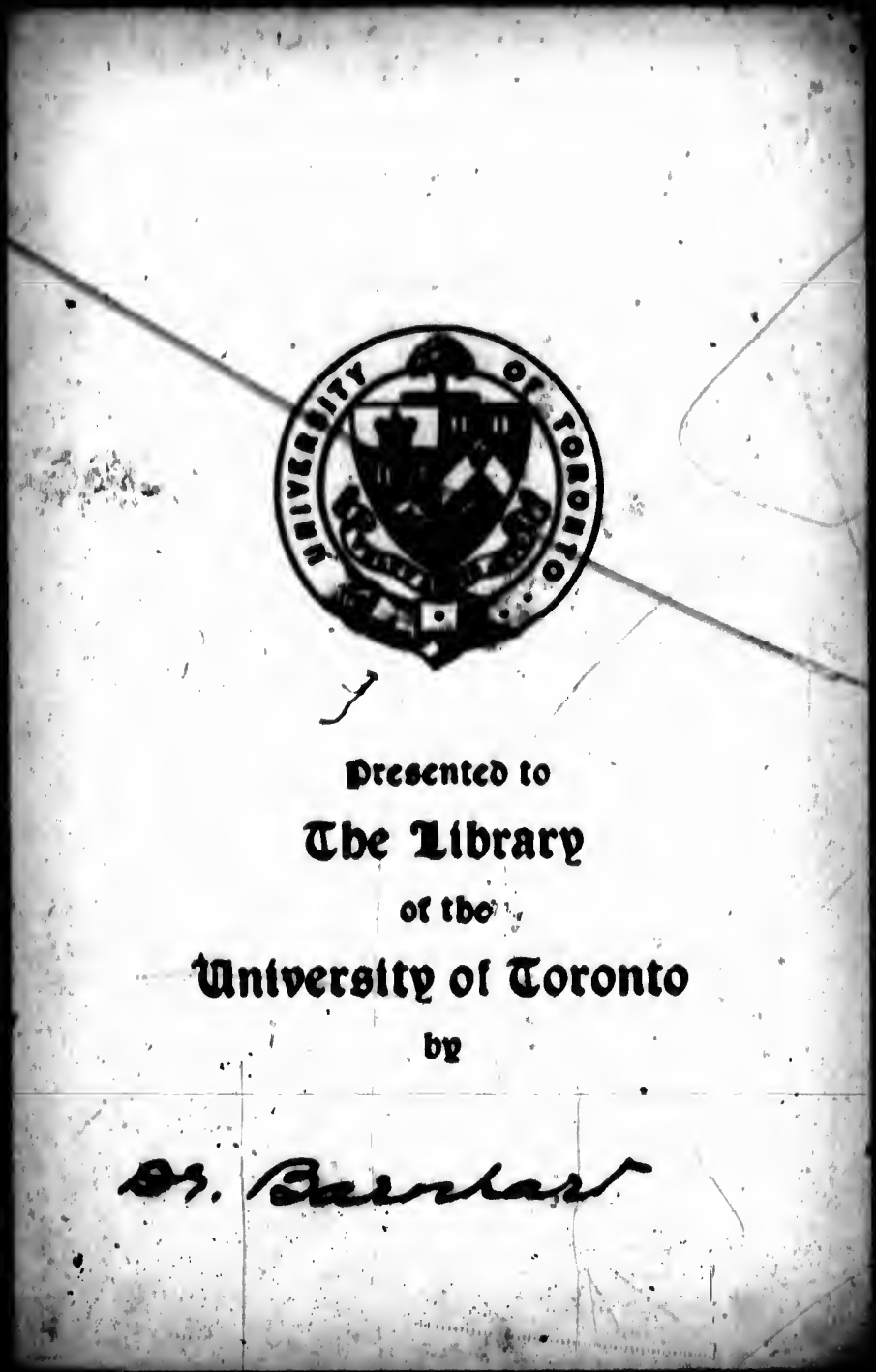




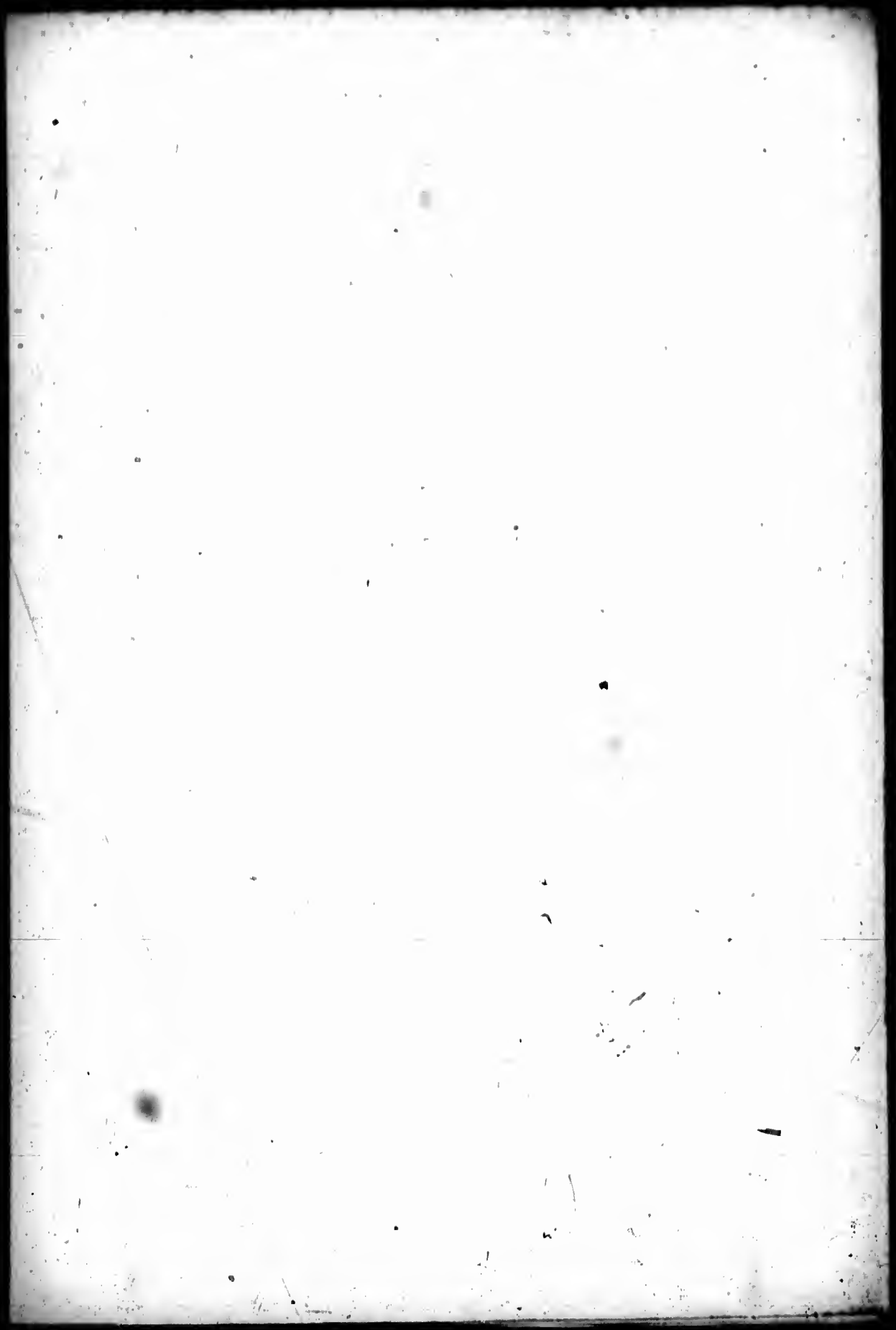





\section{OANADIAN}

\section{FERNS AND WILD FLOWERS,}

COLLECTED IN THE PRovince of

ontario, Canada.

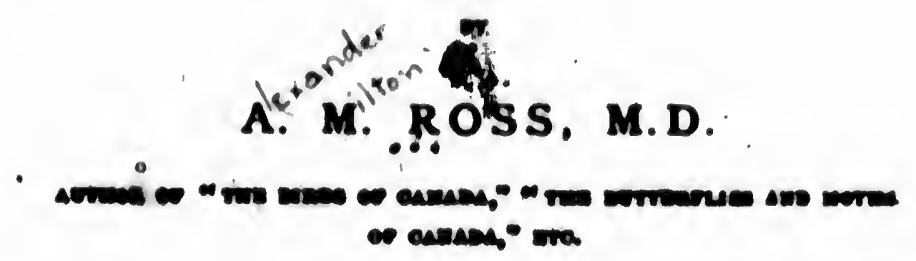

$\mid \begin{aligned} & 13 \\ & \vdots \\ & \vdots\end{aligned}$

- ances

14. " romid

WI ANKAL

QDMUE:N

TOROsTO.

1873. 


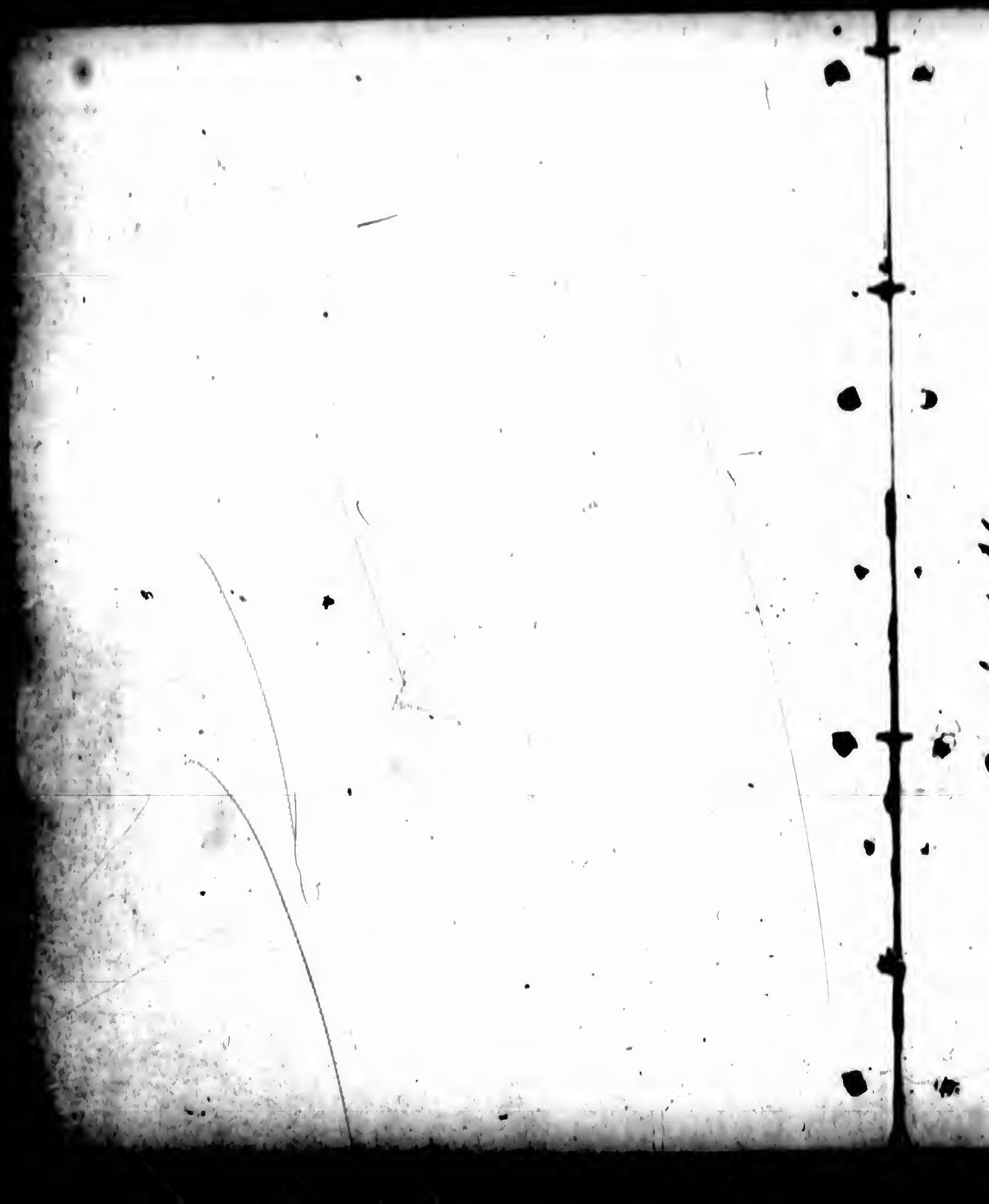




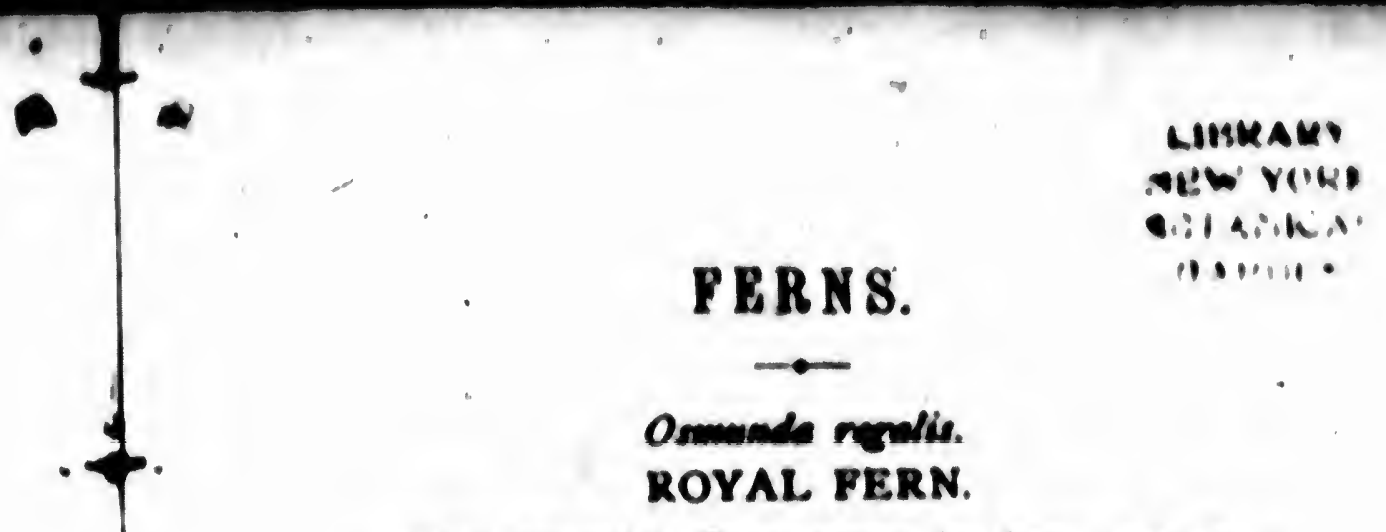

This beauliful Fem gnows in deep, enampy woods.

O. Closplowiona.

CLAYTON'S PLOWERING PERN.

Grows in dark, moist moods, and on deeply shaded hillaidea.

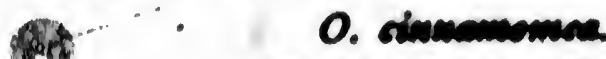

CINNAMON FERN.

Grows in swampen and marahy woods.

\section{Pobjectivin encerers. \\ COMMON POLYPODY FERN.}

Grows on moesy banks.

P. drepperis.

कृ

THREE BRANCHF.D POLYPODY FERN.

Grow in rocky, shaded woods.

P. Pesepenis.

WOODLAND POLYPODY FERN.

Grows on wet, shaded hillsides, in woods. 


\section{P. hexupunopiona.}

\section{IVINGED POLYPODY FERN.}

Grows in open woods.

\section{Pferis aquilima.}

CUMMON BRACKEN FERN.

Grows in open woods, and fields. Very common.

Polystichoum acrostichoiralcs.

TERMINAL, SHIELD FERN.

Grows on the banks of streams in the woods.

P. aculcatuen.

P'RICKLY SHIELD FERN.

Grows in hilly, rocky woods.

Polystichoum lonchitis.

HOLLY LEAVED SHIELD, FERN.

Grows in rocky mountainous woods, in shaded localitics.

\section{P. fragrams}

SWEET SCENTED SHIELD FERN.

Grows in the fissures of mísiy shaded rocks.

Dicksonia punctilobula.

GOSSAMER FERN,

Grows in open woods. 
Jastem isinwlose.

COMMON WUOOD FEKN.

Cirows in damp, bogky woods.

- C.. Iholyperries

SIVAMP SIIILI.D FKKN.

Cirows in marshy places.

I. cristista.

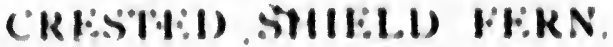

Cirows in dark swampl.

I.. Imargivialis.

MAKRIINAI. IRUITING; SHIIÉLD FIRN.

(irows on rocky hillsides.

1., now iboracrusis. .

NEWV Y(ORK SHIIILD FI:RN.

(jows in high places in woods.

1.. soliticiun.

GOI.DI :S SHIIEI.I) FIKN.

Grows in rich, moist woodr.

Cuorlen scusibilis.

SIENSITIVI: FIERN.

Grows in shaded, damp places. 


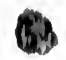

$\infty$

(1)

$r$

(y)

$\therefore$ 
Ophioglacesing endratum.

\section{ADDER'S TONGUE FERN.}

Grows in deeply shaded and damp woods.

Strwothioperris penmotuanica. OSTRICH FERN.

Grows in rich, loamy, shaded ground.

Scolopondrinem vulgare.

HART'S-TONGUE FERN.

Grows in the crevices of shaded rocks.

Woodwardia virginicum.

COMMON CHAIN FERN.

Grows in boggy ground.

Woadsia ilvensis.

COMMON DOWNY HAIR FERN.

Grows on rocks in open woods and fields.

Cystopecris bulpificra.

\section{COMMON BLADDER FERN.}

Grows in the fissures of moist rocky banka.

C. fragilis.

SLENDER BLADDER FERN.

Grows on well-ahaded rocky hill wides,

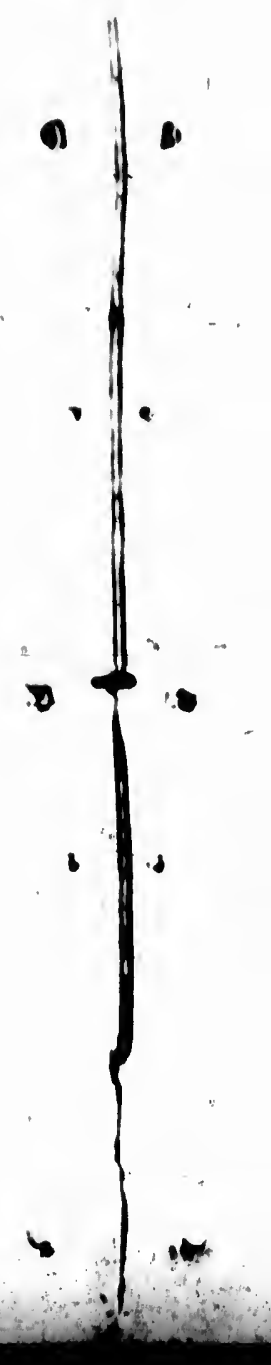




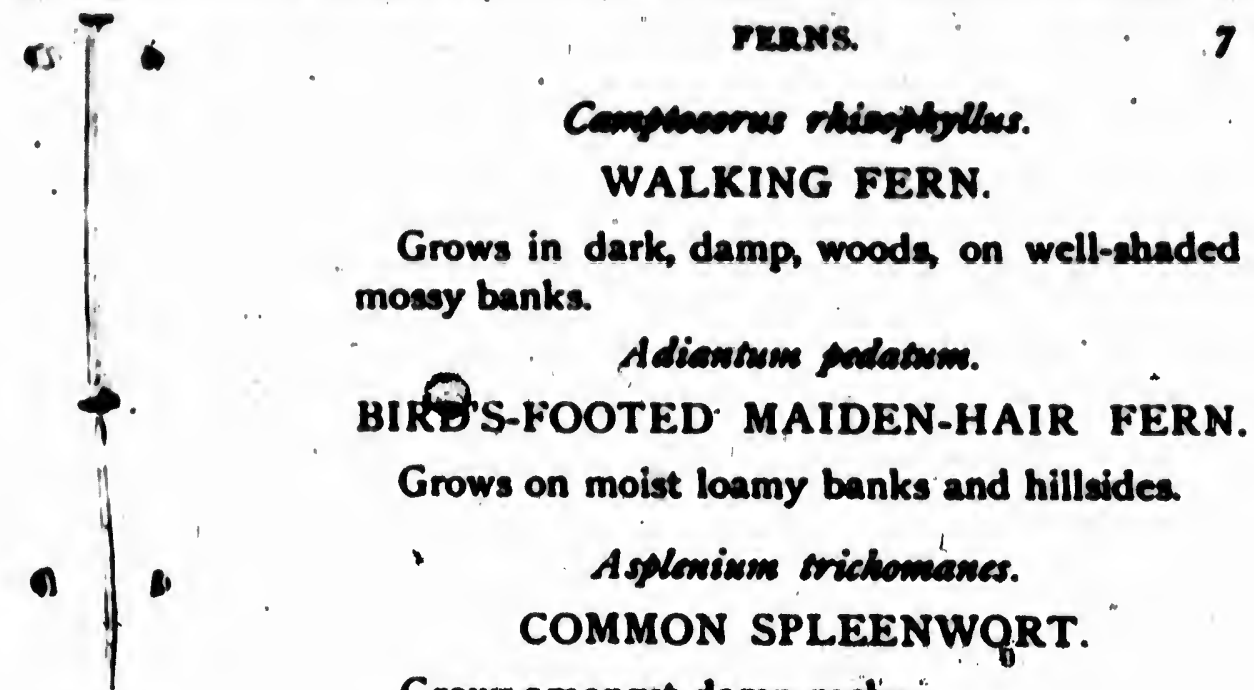

Grows amongat damp rocks.

Asplémimen viriate.

GREEN SPLEENWORT.

Found in crevices of moist rocks.

A. chelypecroides.

SILVERY SPLEENWORT.

Grows in dark, shaded woods.

A. cobrewn:

BLACK STALKED SPLEENWORT.

Grows in open woods.

A. Alim- armina.

LADY FERN.

Grows in moist, daric woods. 
Allosemes atropungureas. PURPLE-STEMMED ROCK BRAKE.

Grows in dark, shaded banks.

A. Eracilis.

SLENDER ROCK BRAKE.

Grows in the crevices of rocks, in dark places.

Botrguchimen virg̈inicuim.

RATTLE SNAKE FERN.

Grows in wet, boggy woods.

B. Inmaria.

COMMON MOONWOKT.

- Grows in open woods.

$$
\begin{gathered}
\text { B. lumarioides. } \\
\text { TALL MOONWORT. }
\end{gathered}
$$

Grows in open, dry woods.

$$
\begin{gathered}
\text { B. simplex. } \\
\text { DWARF MOONWORT. }
\end{gathered}
$$

Grows in dark, damp woods.

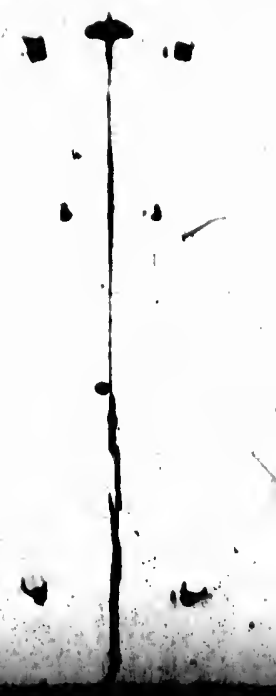




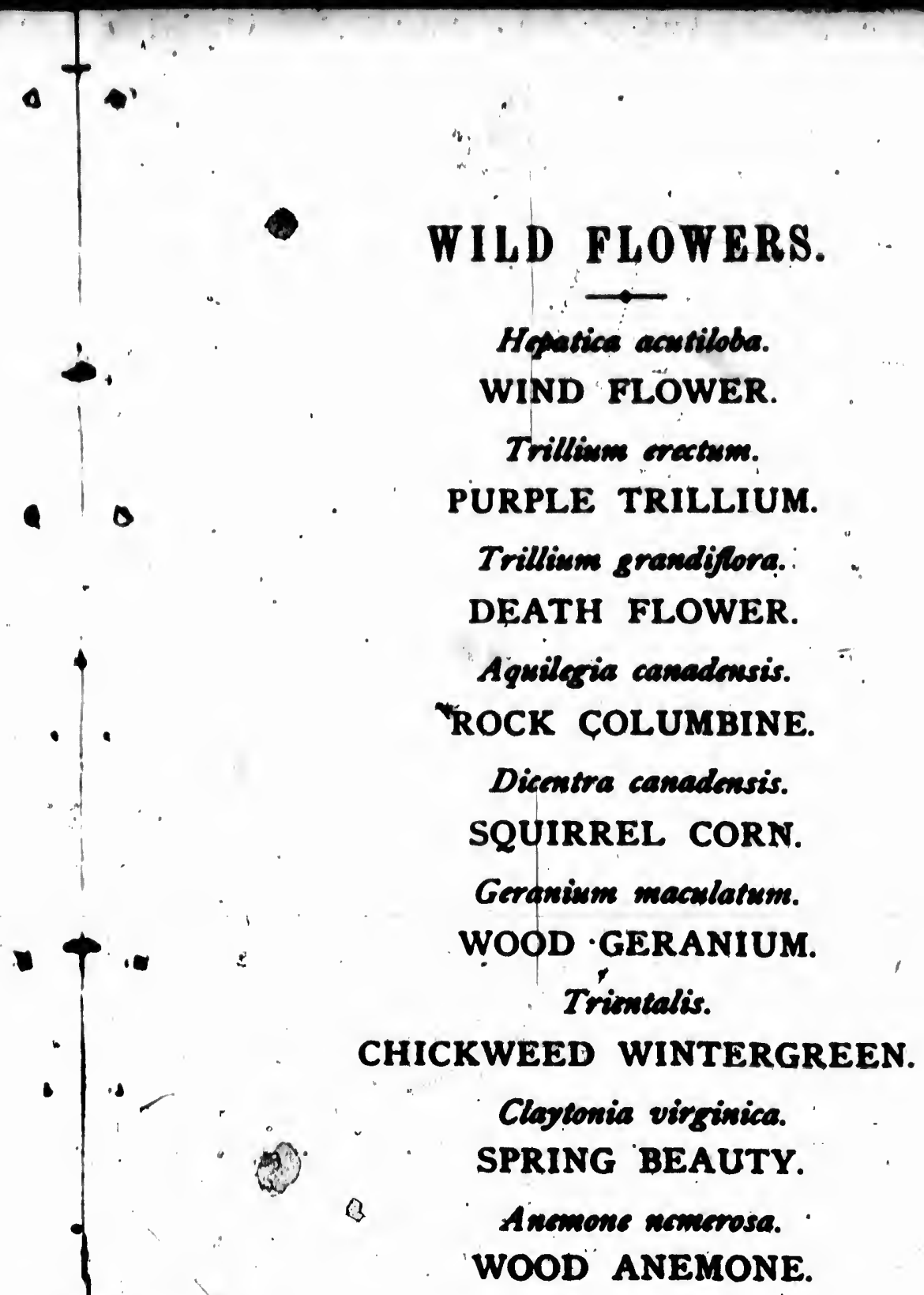




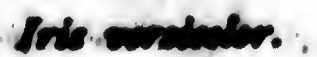

LARG: mUL MaG.

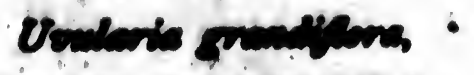

woOD DAPLODILL.

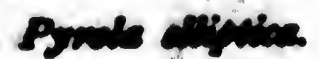

SWRET WINTRERPEN.

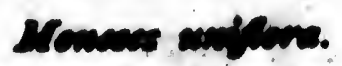

ONE FLOWBRED PYROLA.

Rumbere finisida:

cona mongr.

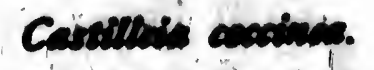
SCARTET CUP.

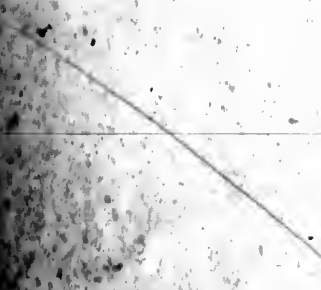

(x), $4,4+2$

$$
\text { Onais gratarlis. }
$$

SHOWX ORCHIS.

$$
\text { INDIAN TULNIR. }
$$

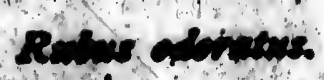

How onte ris sprasix.

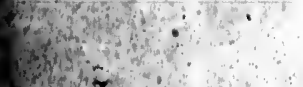

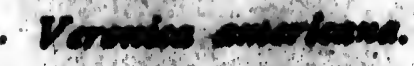

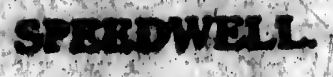

4

0

245 


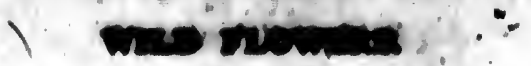

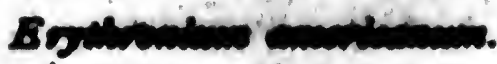

ADDras TOUNUE.

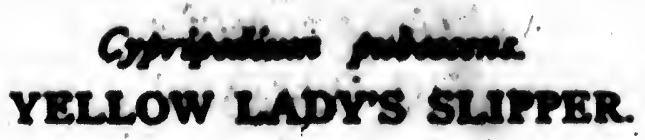

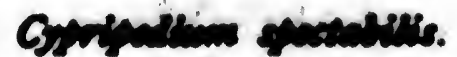

SHOWY LADYS SIIPPER.

\&

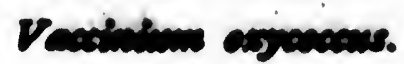
SMALI CRANBRRY.

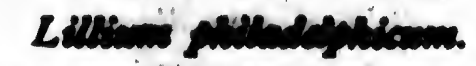
WILD ORANGE LILY.

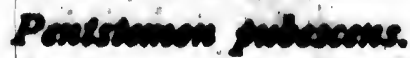

BEARD TOTIGUIS.

Ran Nimes

garly WLL ROSE.

Divin anmonis

CANADA ROSE

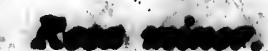

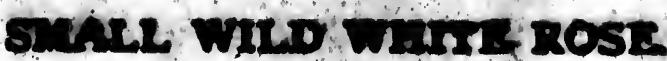

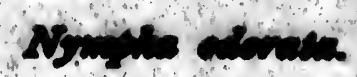
SWIAY SCENIHD WALA tirt. 


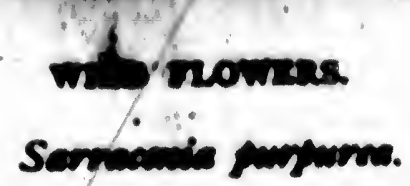

\title{
PITCHER PLANT.
}

\author{
Nisuar alrowa. \\ YELLOW POND LILLY.
}

Campanouls notonodifolia.

CANADA HAREBELL.

\section{NOW IN PRESS.}

- the flona OF carada.

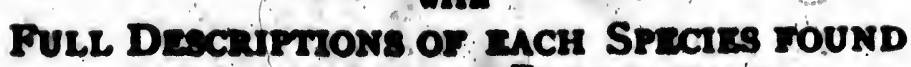
IN THE Drenenter Panvixces of THE Dosmrnos.

A. M. ROSS, M. D.

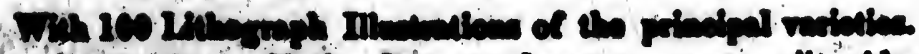

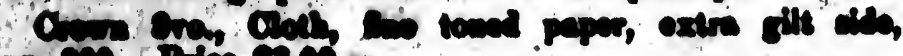

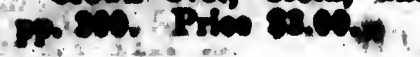






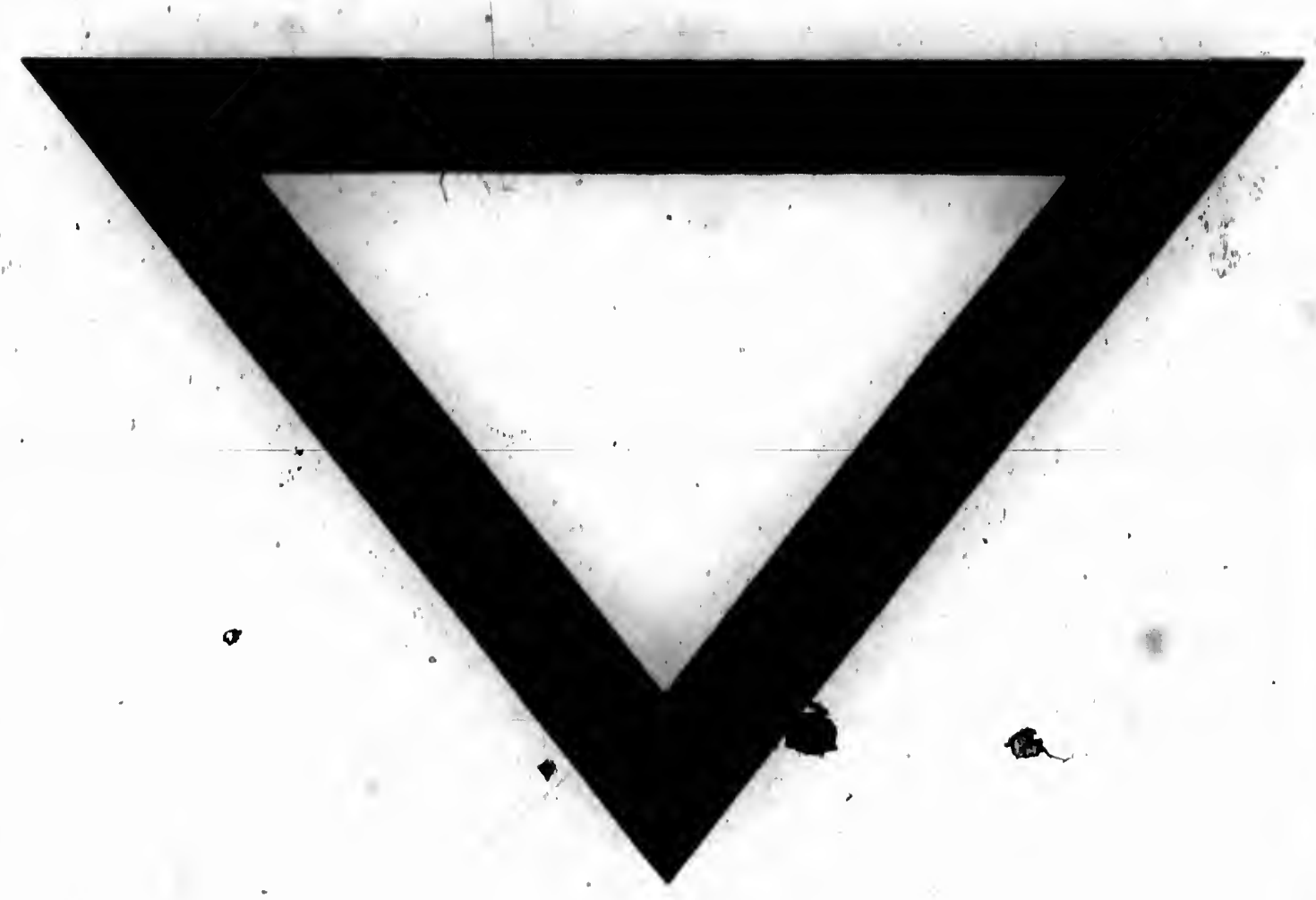




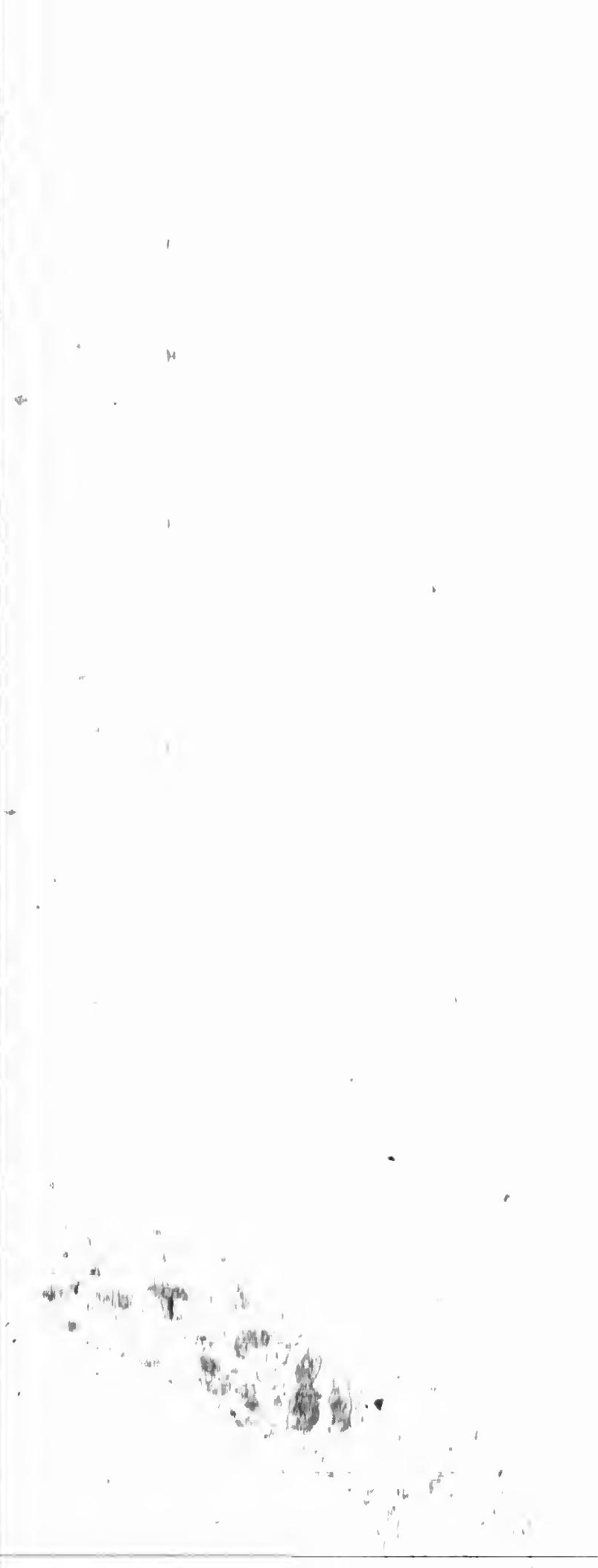




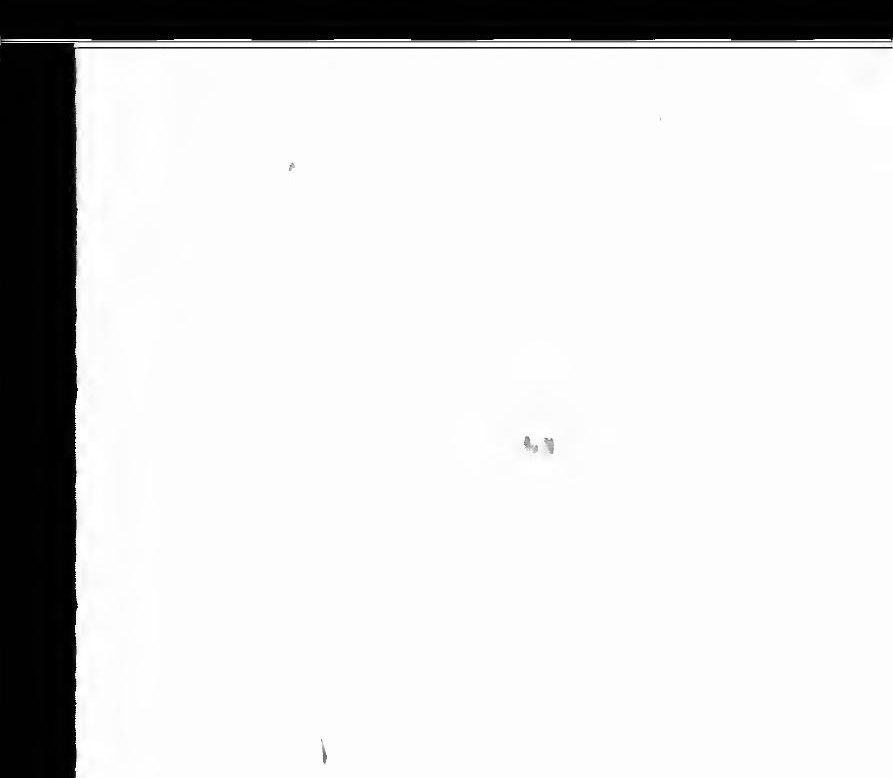




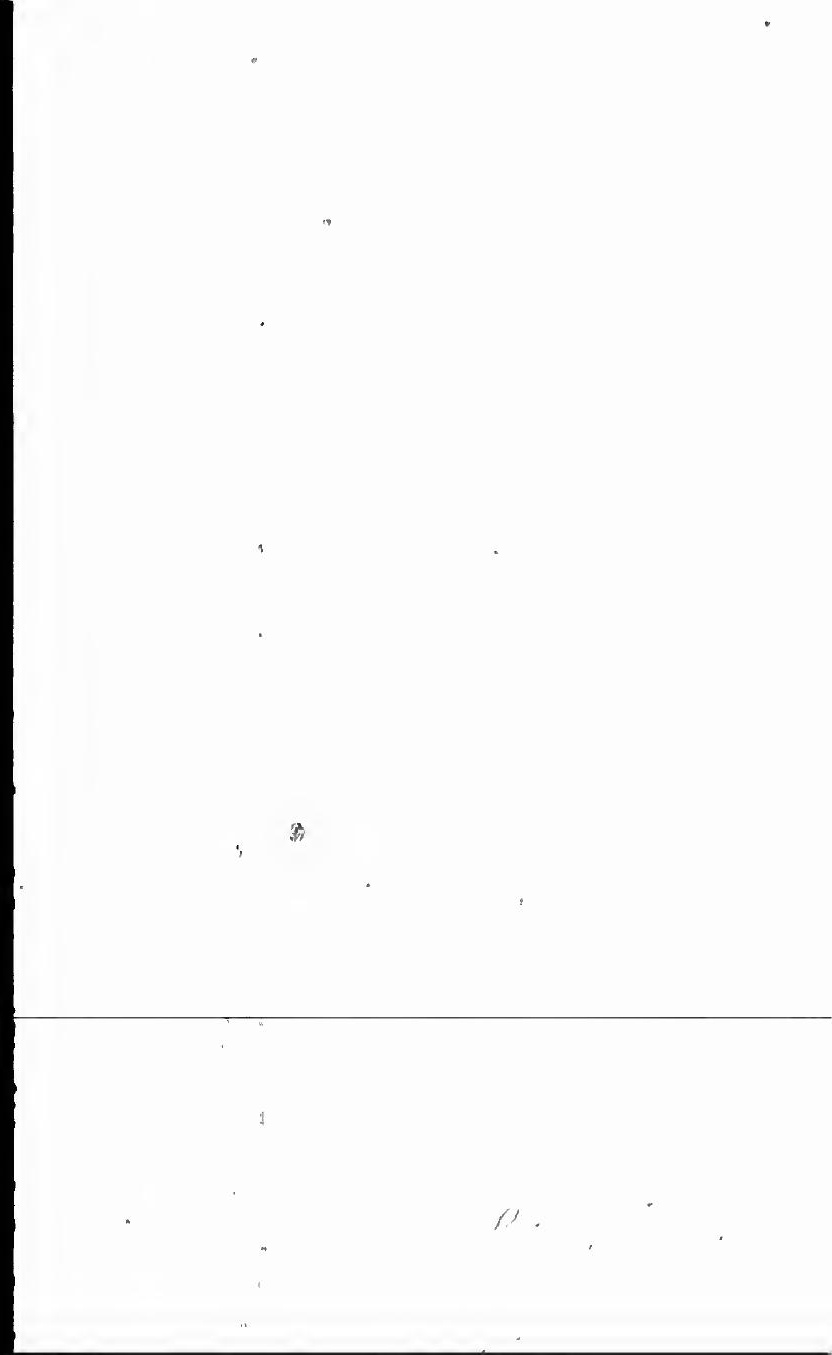

